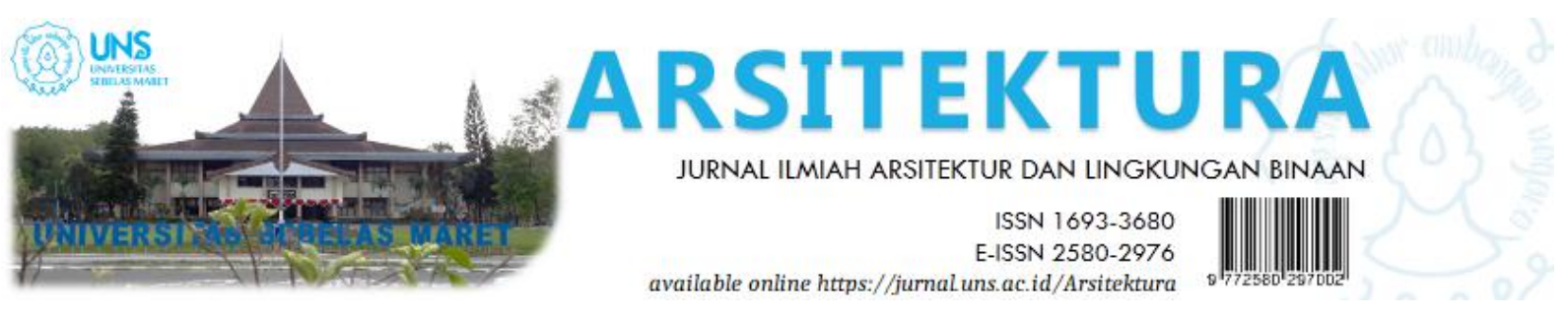

Volume 17 Issue 2 October 2019, pages:211-220

\title{
Pengaruh Ventilasi Alami Terhadap Sick Building Syndrome
}

\section{The Effect of Natural Ventilation on Sick Building Syndrome}

\author{
Fisa Savanti ${ }^{1 *}$, Gagoek Hardiman ${ }^{2}$, Erni Setyowati ${ }^{3}$ \\ Master Program of Architecture, Engineering Faculty, Diponegoro University ${ }^{1 *}$ \\ Email : fisasavanti@students.undip.ac.id* \\ Department of Architecture, Engineering Faculty, Diponegoro University ${ }^{2}$ \\ Department of Architecture, Engineering Faculty, Diponegoro University ${ }^{3}$
}

DOI: https://doi.org/10.20961/arst.v17i2.30440

Received: May 31, 2019 Revised: October 4, $2019 \quad$ Accepted: October 4, $2019 \quad$ Available online:October 31, 2019

\begin{abstract}
The number of buildings that use air conditioner (AC), causing a lack of air change rate from the outside into the room or vice versa that can reduce indoor air quality. A bad indoor air quality is often give rise to complaints on its occupants called the "Sick Building Syndrome" (SBS). The presence of ventilation is expected to improve air quality and increase user comfort and wellness rooms. Therefore, the research on the influence of natural ventilation against sick building syndrome (SBS) is needed. This research was conducted with quantitative-descriptive methods with direct measurements of temperature, humidity and vloumetric air flow rate on samples of objects namely RSND clinic waiting room on the 2nd floor. As for analysis is carried out descriptively based on recommended standards. The purpose of doing this research is to know the influence of natural ventilation to the indoor air quality towards sick buiding syndrome. The result of this research show that the temperature, humidity and the clean air needs of the room doesn't meet the standarts, meanwhile the air change per hour meet the standarts on some spots. So, there is some influence of the use of natural ventilation that can improve the indoor air quality which is relating to sick building syndrome.
\end{abstract}

Keywords: ventilation, indoor air quality, sick building syndrome, hospital

\section{PENDAHULUAN}

\subsection{Latar Belakang}

Kualitas udara di dalam ruang dipengaruhi oleh kondisi ventilasi (Kelly, Maupetit, \& Robine, 2002) dan akumulasi pencemar udara yang bersumber dari dalam serta luar ruang. (Talarosha, 2018). Menurut National Institute Of Occupational Safety and Health (NIOSH) 1997 (U.S. Department Of Health And Human Services 2011) dalam (Jayanti, Manyullei, \& Bujawati, 2016) penyebab timbulnya masalah kualitas udara dalam ruangan pada umumnya disebabkan beberapa hal, yaitu kurangnya ventilasi udara (52\%), adanya sumber kontaminan dari luar ruangan $(10 \%)$, mikroba $(5 \%)$, bahan material bangunan (4\%), dan lainlain $(3 \%)$.

Kualitas udara yang buruk dalam ruangan sering menimbulkan keluhan pada penghuninya seperti sakit kepala, tenggorokan kering, iritasi pada mata dan kulit, kehilangan konsentrasi dan menurutnya prestasi kerja atau yang biasa disebut "Sick Building Syndrome" (Moerdjoko, 2004). Sistem ventilasi dan sirkulasi udara yang buruk merupakan salah satu faktor penyebab Sick Building Syndrome. Kemungkinan 
terburuknya adalah tidak terjadi proses sirkulasi udara di dalam maupun di luar ruang. Dengan kata lain sistem ventilasi tersebut yang ada hanya mensirkulasikan "udara buruk" di dalam ruang. (Camelia, 2011).

Pada penelitian yang dilakukan oleh (Moerdjoko, 2004) dinyatakan bahwa terdapat hubungan yang bermakna (signifikan) secara statistik antara jumlah koloni mikroorganisme pada ruangan ber-AC dan ruangan tidak ber-AC (ventilasi alami) dengan kemungkinan adanya mikroorganisme pada ruangan tanpa $\mathrm{AC}$ lebih besar dari pada ruangan yang menggunakan AC. Sirkulasi udara juga berperan cukup signifikan terhadap jumlah koloni mikroorganisme. Lokasi yang mempunyai sirkulasi udara buruk kemungkinan untuk mengandung mikroorganisme udara lebih tinggi dibandingkan lokasi dengan sirkulasi udara baik, pada ruang tanpa $\mathrm{AC}$ maupun ruang ber-AC. Sedangkan menurut urutan besarnya pengaruh terhadap jumlah koloni mikroorganisme udara pada ruang ber $\mathrm{AC}$ dan tanpa AC adalah sirkluasi udara, temperatur udara, sistem ventilasi (ber- AC/ tanpa AC) dan kelembaban.

Pada penelitian yang dilakukan oleh (Rachmatantri, Hadiwidodo, \& Huboyo, 2015) menyatakan bahwa sistem ventilasi dan keberadaan manusia dalam ruangan berpengaruh terhadap keberadaan koloni mikroba udara. Selain itu, beberapa variabel perancu yang mempengaruhi keberadaan mikroorganisme udara menurut urutan besaran pengaruh terhadap jumlah koloni mikroba udara adalah suhu, kelembaban dan intensitas cahaya.

Begitu pula penelitian yang dilakukan oleh (Vidyautami, Huboyo, \& Hadiwidodo, 2015) menyatakan adanya pengaruh penggunaan ventilasi (AC dan Non AC) terhadap keberadaan mikroorganisme. Dan diantara parameter suhu, kelembaban dan intensitas cahaya yang mempengaruhi jumlah mikroba paling besar yaitu kelembaban. Hal ini menunjukkan adanya pengaruh antara ventilasi (AC dan Non AC) terhadap banyaknya mikroorganisme.

Namun penelitian-penelitian tersebut tidak dilakukan pada objek Rumah Sakit yang memiliki kaitan erat dengan pelayanan kesehatan. Banyaknya bangunan yang menggunakan penghawaan buatan berupa AC menyebabkan minimnya pergantian udara dari atau ke dalam ruangan bila dibandingkan dengan penghawaan alami. Hal ini dapat mengurangi kualitas udara di dalam ruangan dan mempengaruhi kesehatan penggunanya. Oleh karena itu, perlu adanya penelitian mengenai pengaruh ventilasi alami (untuk mengurangi konsumsi energi) terhadap Sick Building Syndrome atau yang sering disebut SBS pada Rumah Sakit yang erat kaitannya dengan kesehatan, khususnya Instalasi Rawat Jalan/ Poliklinik dimana berbagai pasien dengan berbagai jenis penyakit berkumpul dalam satu ruang.

Penghawaan alami yang sumbernya dari tiupan angin yang sudah tersedia di alam (bukan hasil rekayasa) dan masuk melalui ventilasi akan memudahkan pertukaran udara, dari luar ke dalam ruangan maupun sebaliknya, sehingga diharapkan dapat memperbaiki kualitas udara dan meningkatkan kenyamanan serta kesehatan pengguna ruangan tersebut.

Pertukaran udara memiliki banyak manfaat bagi kesehatan manusia. Adanya pertukaran udara ini akan menghilangkan reaksi bahan kimia berbahaya antara endapan uap air hasil dari kegiatan manusia dengan zat-zat kimia yang terkandung dalam pelapis dinding dan benda-benda dalam ruang. Zat-zat berbahaya tersebut akan terhirup oleh manusia jika tidak ada sirkulasi udara yang baik dalam ruang dan dapat menimbulkan penyakit dalam tubuh. (Juliana Bekti Susilaning Budi, Khairunnisa Fifthariski, Sri Yuliani, 2018).

Dengan mengacu pada Peraturan Menteri Kesehatan RI Nomor 1204/Menkes/SK/X/2004 Tentang Persyaratan Kesehatan Lingkungan Rumah Sakit, seperti luas ventilasi alamiah minimum 15\% dari luas lantai serta standar suhu dan kelembaban menurut fungsi ruang dan unit sebagai ruang administrasi yaitu $21-24{ }^{\circ} \mathrm{C}$, kelembaban 35-60\% (Menteri Kesehatan Republik Indonesia, 2004). Sedangkan berdasarkan Keputusan Menteri Kesehatan No.261/MENKES/SK/II/1998 temperatur ruangan yang sehat berkisar antara $18^{\circ} \mathrm{C}-26^{\circ} \mathrm{C}$ (Menteri Kesehatan Republik Indonesia, 1998). Manusia sendiri memiliki kebutuhan sebagai berikut: 
- Kebutuhan akan suhu nyaman $18^{\circ} \mathrm{C}-25^{\circ} \mathrm{C}$ dan kelembaban udara 40\%-70\%.

- Kebutuhan udara bersih $0,84 \mathrm{~m}^{3} / \mathrm{org} /$ menit.

- Kebutuhan akan kecepatan angin yang nyaman 0,2-2 $\mathrm{m} /$ detik. (Anam et al., 2014).

Pergantian udara bersih yang dibutuhkan dan volume ruang akan memenuhi persyaratan tersedianya udara bersih. Menurut (Syamsiyah Nur. R, 1995) dalam (Anam et al., 2014) rumah sakit sebaiknya memiliki arus udara bersih 0,9 $1,2 \mathrm{~m}^{3} /$ menit/orang dengan volume ruang 5,5 $>30 \mathrm{~m}^{3} /$ orang. Sedangkan pergantian udara tiap jam dapat dihitung dengan menggunakan persamaan di bawah ini;

$$
\mathrm{N}=\frac{3600 \mathrm{Q}}{\mathrm{V}}
$$

Dimana $\mathrm{N}$ adalah nilai pergantian udara untuk tiap jam (kali/jam), sedangkan $Q$ adalah volumetric flow rate (volume udara masuk ruangan) $\left(\mathrm{m}^{3} / \mathrm{s}\right)$. V adalah volume dari ruangan atau bangunan $\left(\mathrm{m}^{3}\right)$ dan 3600 adalah faktor konversi (dari sekon menjadi hour).

Berdasarkan (Kementrian Kesehatan Republik Indonesia, 2012) tentang Pedoman Teknis Prasarana Sistem Tata Udara Pada Bangunan Rumah Sakit, total pertukaran udara perjam untuk ruang administrasi dan ruang tunggu rumah sakit yaitu minimum $6 \mathrm{kali} / \mathrm{jam}$.

\subsection{Tujuan Penelitian}

Penelitian ini bertujuan untuk mengetahui pengaruh ventilasi alami terhadap kualitas udara. Dalam berkegiatan sehari-hari memerlukan kualitas udara yang baik, khususnya melalui desain ventilasi alami yang baik, sehingga tidak perlu menambah pengkondisian udara buatan yang dapat menambah beban energi bangunan.

\section{METODE}

Penelitian dilakukan dengan metode kuantitatif-deskriptif yang mengambil sampel pada ruang tunggu poliklinik (lantai 2) Rumah Sakit Nasional Diponegoro sebagai ruang yang terdapat bukaan/ventilasi alami.

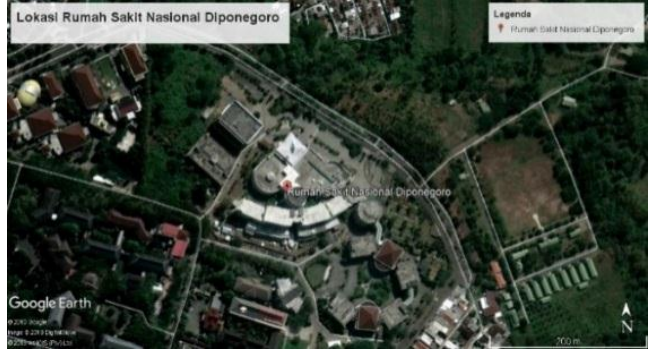

Gambar 1. Lokasi RSND

Sumber : google earth, 2019.

Dalam penelitian ini diambil data untuk mengetahui kualitas udara dalam ruang yang berkaitan dengan fenomena sick building syndrome. Variabel yang dibutuhkan berupa data pengukuran suhu, kelembaban dan volumetric air flow rate serta penghitungan nilai pergantian udara per jam. Pengambilan data ini dilakukan secara langsung ke lapangan pada hari Jumat, 12 April 2019, yaitu pada pagi hari pukul 09.00 dan siang hari pukul 14.00 dalam kondisi jendela terbuka semua dan tertutup semua (lihat gambar 1 dan 2). Selanjutnya analisis data dilakukan secara deskriptif berdasarkan standar kesehatan/ kualitas udara dalam ruang yang kemudian dikaitkan dengan fenoma sick buiding syndrome.

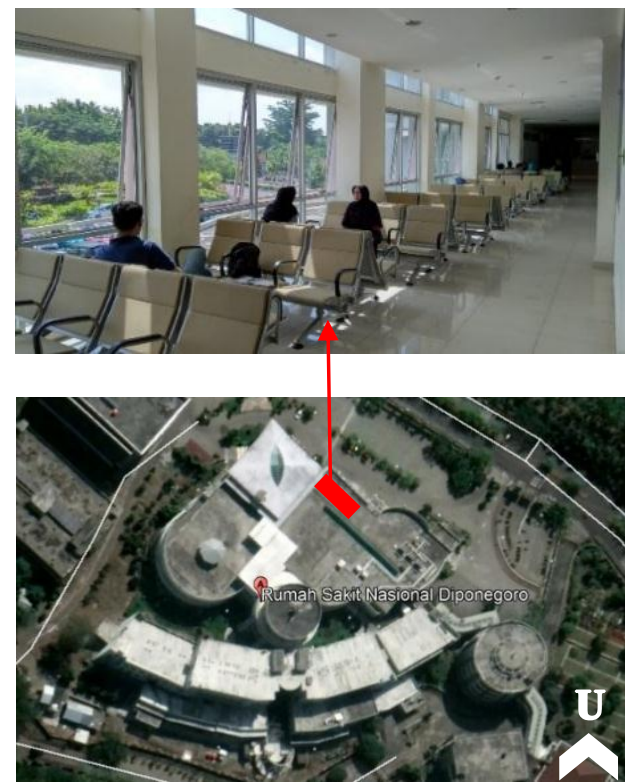

Gambar 2. Letak ruang tunggu poliklinik pada gedung dan kondisi eksistingnya Sumber: Google Erath, 2019. 
Rumah Sakit Nasional Diponegoro dibagi menjadi 3 gedung dalam pelayanannya, yaitu gedung A, B dan C. Ruang tunggu poliklinik ini berada pada gedung A RSND lantai 2. Orientasi bukaan hanya pada satu sisi saja yaitu pada sisi timur laut sehingga sinar matahari lebih banyak masuk pada pagi hari dan terbayangi pada siang hari serta minimnya cross ventilation. Posisi tempat duduk yang mendekat ke arah bukaan, dan pada sisi yang lain digunakan sebagai sirkulasi pengunjung maupun pasien.

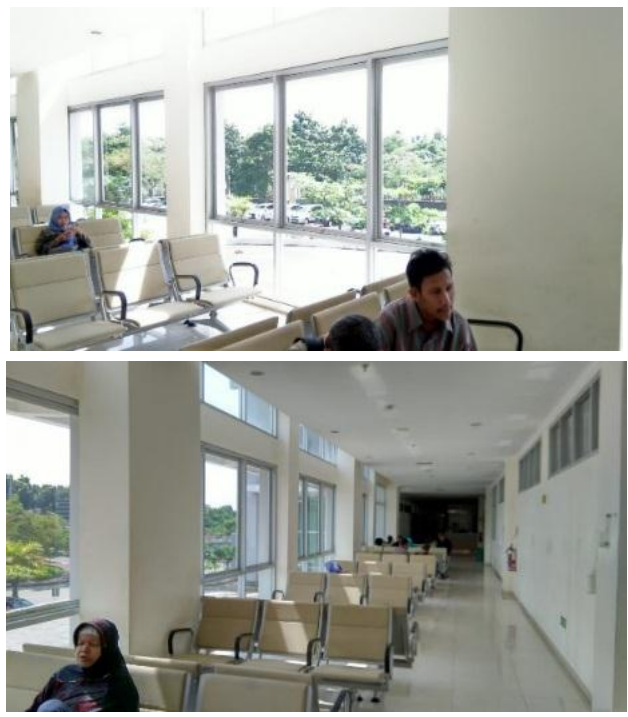

Gambar 3. Kondisi ruang tunggu poliklinik saat ventilasi tertutup semua

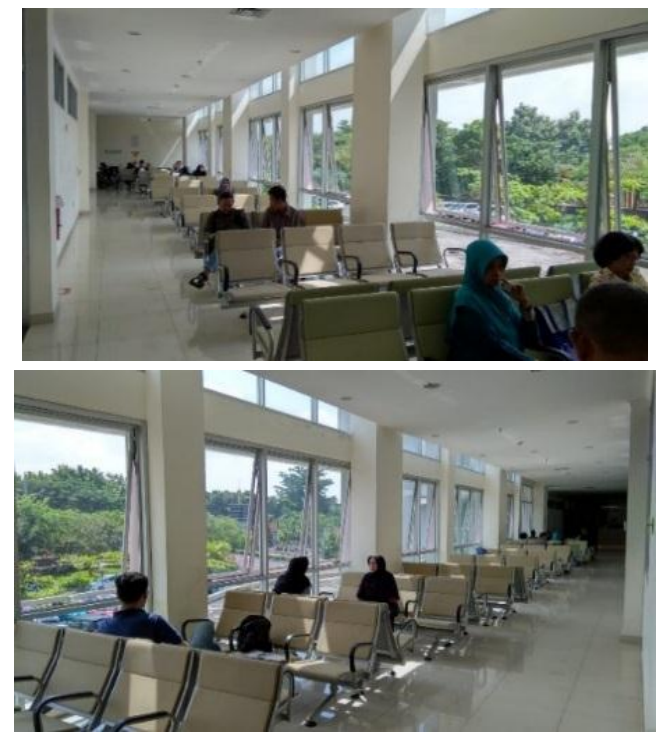

Gambar 4. Kondisi ruang tunggu poliklinik saat ventilasi terbuka semua
Alat yang digunakan:

Table 1. Alat yang digunakan dan fungsinya

\begin{tabular}{ll}
\hline $\begin{array}{l}\text { Termo- } \\
\text { higrometer }\end{array}$ & $\begin{array}{l}\text { Untuk mengukur suhu dan } \\
\text { kelembaban dalam ruang }\end{array}$ \\
\hline $\begin{array}{l}\text { Hot wire } \\
\text { anenometer }\end{array}$ & $\begin{array}{l}\text { Untuk mengukur } \\
\text { volumetric air flow rate } \\
\text { dalam ruang }\end{array}$ \\
\hline Jam tangan & $\begin{array}{l}\text { Untuk menentukan waktu } \\
\text { pengukuran }\end{array}$ \\
\hline $\begin{array}{l}\text { Laser } \\
\text { distance } \\
\text { meter }\end{array}$ & $\begin{array}{l}\text { Untuk menukur luas } \\
\text { bukaan/ ventilasi pada } \\
\text { ruang }\end{array}$ \\
\hline
\end{tabular}

\section{HASIL DAN PEMBAHASAN}

\subsection{Data Pengukuran}

\section{Penentuan Titik Pengukuran}

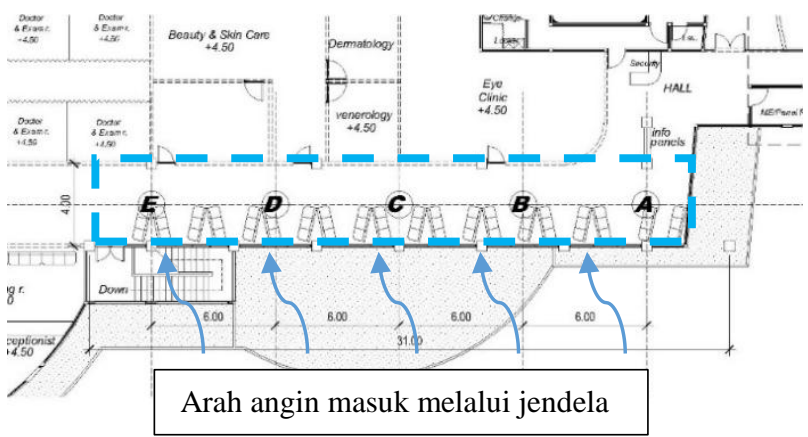

Gambar 5. Penentuan Titik Pengukuran

Pengukuran diambil pada ketinggian $\pm 60 \mathrm{~cm}$ dari lantai sesuai dengan ketinggian orang duduk.

Table 2. Data Ruang Tunggu Poliklinik RSND lantai 2

\begin{tabular}{ll}
\hline Luas ruang & $124 \mathrm{~m}^{2}$ \\
\hline Tinggi plafond & 2,9 meter \\
\hline $\begin{array}{l}\text { Kapasitas kursi yang } \\
\text { disediakan }\end{array}$ & 76 buah kursi \\
\hline Volume Ruang & $\left(359,6 \mathrm{~m}^{3} / 76\right)=$ \\
& $4,73 \mathrm{~m}^{3} / \mathrm{orang}$ \\
\hline Luas bukaan jendela & $(1,683 \mathrm{x} \mathrm{15buah)}=$ \\
& $25,245 \mathrm{~m}^{2} ;$ \\
& $20 \%$ dari luas lantai \\
\hline Luas bukaan pintu & $1,484 \mathrm{~m}^{2}$ \\
\hline Orientasi bukaan & Timur laut \\
\hline
\end{tabular}


Jumlah luas bukaan pada ruang tunggu poliklinik RSND ini sebesar $20 \%$ dari luas lantai, dengan demikian sudah memenuhi standar minimal pada Peraturan Menteri Kesehatan RI Nomor 1204/Menkes/SK/X/2004 Tentang Persyaratan Kesehatan Lingkungan Rumah Sakit, yaitu 15\% dari luas lantai.

Sedangkan volume ruang $4,73 \mathrm{~m}^{3} /$ orang dengan kapasitas 76 orang masih kurang dari standar minimum menurut (Syamsiyah Nur. R, 1995) dalam (Anam et al., 2014) yaitu 5,5 - >30 $\mathrm{m}^{3}$ /orang. Hal ini menunjukkan density ruang masih masih terlalu tinggi dimana ruangan tersebut berupa koridor yang juga digunakan sebagai sirkulasi pengunjung maupun pasien.

\section{Bukaan/ Ventilasi Pada Ruang}
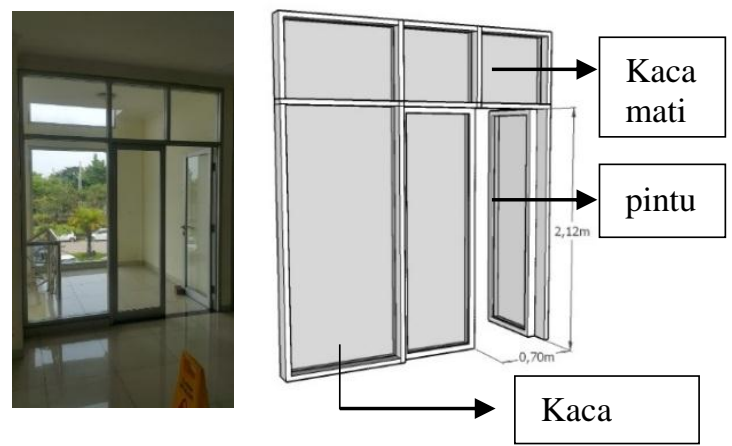

Gambar 6. Bukaan pintu ruang tunggu poliklinik RSND

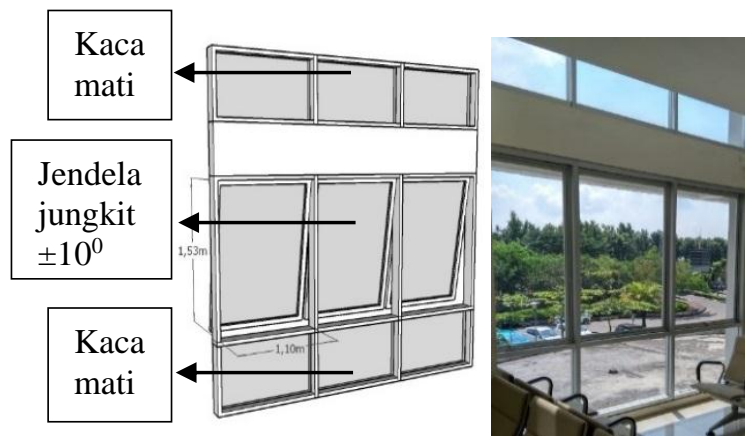

Gambar 7. Bukaan jendela ruang tunggu poliklinik RSND

Jendela jungkit ini hanya bisa dibuka kurang lebih $10^{\circ}$ berjumlah 15 jendela.

\subsection{Pengukuran Lapangan}

\section{Hasil Pengukuran Suhu, Kelembaban dan Volumetric Air Flow Rate}

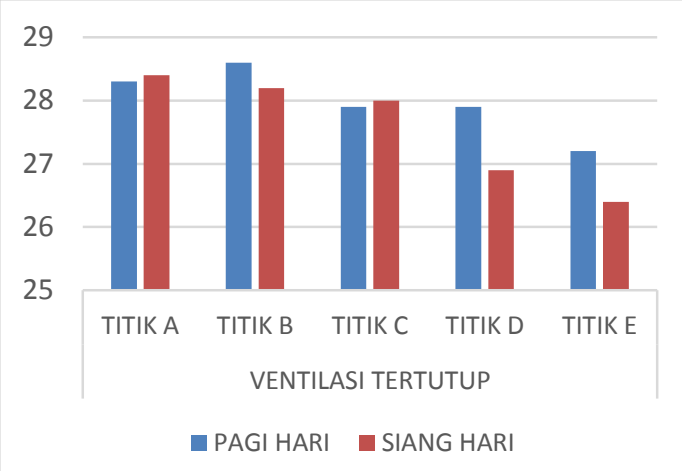

Gambar 8. Diagram Hasil Pengukuran Suhu Saat Ventilasi Tertutup $\left({ }^{0} \mathrm{C}\right)$

Pada saat ventilasi tertutup, suhu pada titik A dan titik $\mathrm{B}$ cenderung lebih tinggi dari titik lainnya baik pada pagi hari maupun pada siang hari yaitu sekitar $28,2^{\circ} \mathrm{C}$ hingga $28,6^{\circ} \mathrm{C}$. Suhu juga cenderung menurun dari titik A hingga ke titik E baik pada pagi hari maupun siang. Suhu terendah dalam ruangan yaitu pada titik $\mathrm{E}$ setinggi $27,2^{\circ} \mathrm{C}$ pada pagi hari dan $26,4^{\circ} \mathrm{C}$ pada siang hari. Hal ini disebabkan titik E dekat dengan nurse station yang menggunakan AC. Secara keseluruhan, suhu pada pagi hari cenderung lebih tinggi bila dibanding dengan suhu pada siang hari. Hal ini disebabkan arah orientasi ruangan yang menghadap ke arah timur laut, sehingga banyak lebih banyak mendapatkan sinar matahari pada pagi hari. Suhu dalam ruang tersebut melebihi standar Peraturan Menteri Kesehatan RI Nomor 1204/Menkes/SK/X/2004 Tentang Persyaratan Kesehatan Lingkungan Rumah Sakit yaitu berada diatas $24^{\circ} \mathrm{C}$. Hal ini disebabkan penggunaan material kaca yang memungkinkan radiasi matahari juga ikut masuk ke dalam ruang.

Suhu dalam ruangan dapat mempengaruhi kualitas udara di dalamnya, semakin tinggi suhu, maka jumlah koloni mikroba akan cenderung banyak, dan semakin rendah suhu, maka jumlah koloni mikroba akan cenderung sedikit. (Rachmatantri et al., 2015) 


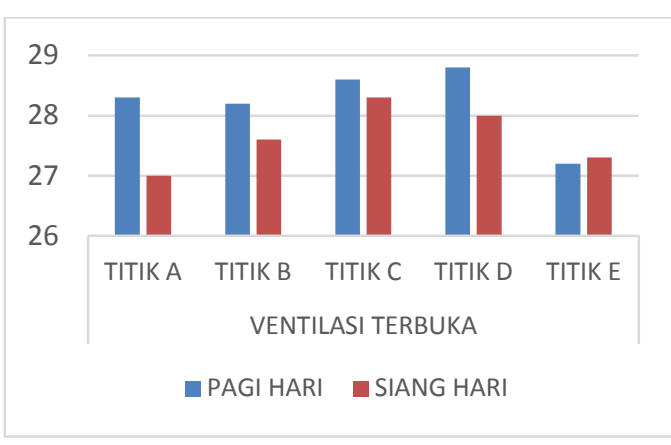

Gambar 9. Diagram Hasil Pengukuran Suhu Saat Ventilasi Terbuka $\left({ }^{\circ} \mathrm{C}\right)$

Pada saat ventilasi terbuka, suhu pada ruangan cenderung fluktuatif, namun pada titik $\mathrm{C}$ dan titik D cenderung lebih tinggi dari titik lainnya baik pada pagi hari maupun pada siang hari yaitu sekitar $28,6^{\circ} \mathrm{C}$ hingga $28,8^{\circ} \mathrm{C}$ pada pagi hari sekitar $28^{\circ} \mathrm{C}$ hingga $28,3^{\circ} \mathrm{C}$ pada siang hari. Sedangkan suhu terendah pada kondisi ventilasi terbuka yaitu pada suhu $27^{\circ} \mathrm{C}$, dengan demikian suhu dalam ruang masih juga melebihi standar Peraturan Menteri Kesehatan Republik Indonesia Nomor 1204/Menkes/SK/X/2004 Tentang Persyaratan Kesehatan Lingkungan Rumah Sakit yaitu berada diatas $24^{\circ} \mathrm{C}$. Namun suhu cenderung menurun bila dibandingkan pada saat ventilasi tertutup meskipun tidak terlalu signifikan. Hal ini disebabkan adanya aliran udara yang masuk sehingga dapat sedikit menurunkan suhu dalam ruang.

Menurut Panduan Pengguna Bangunan Gedung Hijau Jakarta Berdasarkan Peraturan Gubernur No.38/2012 : Vol 2 Sistem Pengkondisian Udara \& Ventilasi, Toleransi terhadap suhu yang tinggi dapat dilakukan dengan meningkatkan aliran udara dalam ruangan. (Pemerintah Provinsi DKI Jakarta, 2012).

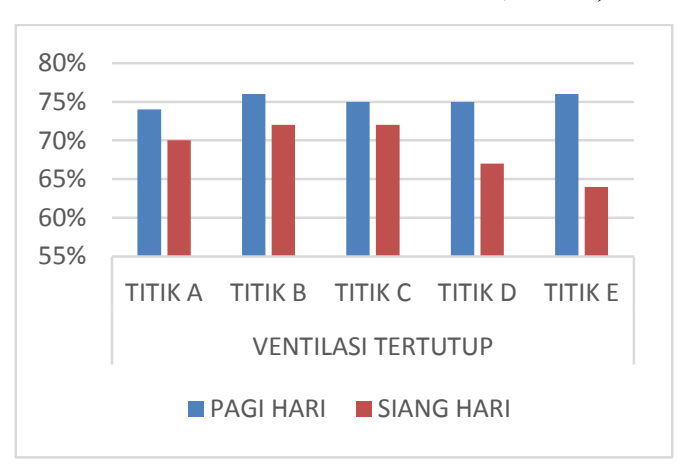

Gambar 10. Diagram Hasil Pengukuran Kelembaban Relatif Saat Ventilasi Tertutup (\%)
Kelembaban pada saat ventilasi tertutup cenderung cukup stabil antar titiknya, pada pagi hari $74 \%$ hingga $76 \%$ sedangkan pada siang hari $64 \%$ hingga $72 \%$. Namun secara keseluruhan masih melebihi standar yang dianjurkan pada Peraturan Menteri Kesehatan RI Nomor 1204/Menkes/SK/X/2004 Tentang Persyaratan Kesehatan Lingkungan Rumah Sakit.yaitu melebihi $60 \%$. Hal ini disebabkan oleh kurangnya aliran udara yang masuk ke dalam ruangan saat ventilasi tertutup.

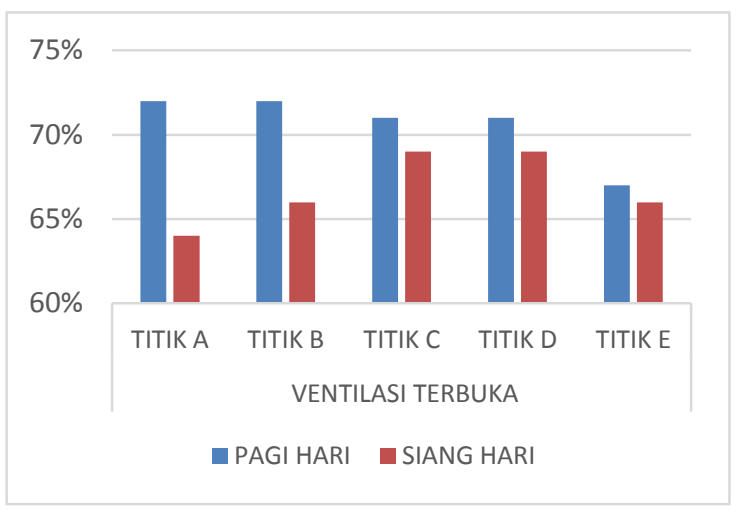

Gambar 11. Diagram Hasil Pengukuran

Kelembaban Relatif Saat Ventilasi Terbuka (\%)

Kelembaban pada saat ventilasi terbuka juga cenderung cukup stabil antar titiknya. Pada pagi hari $67 \%$ hingga $72 \%$ sedangkan pada siang hari $64 \%$ hingga $69 \%$. Walaupun lebih rendah bila dibandingkan pada saat ventilasi tertutup, tingkat kelembaban ruang masih melebihi standar yang dianjurkan pada Peraturan Menteri Kesehatan RI Nomor 1204/Menkes/SK/X/2004 Tentang Persyaratan Kesehatan Lingkungan Rumah Sakit.yaitu melebihi $60 \%$.

Tingkat kelembaban ini dipengaruhi oleh ventilasi. Ventilasi yang kurang dapat menyebabkan kelembaban bertambah, kurangnya pertukaran udara juga akan mempengaruhi keberadaan mikroorganisme Mukono dalam (Vidyautami et al., 2015). 


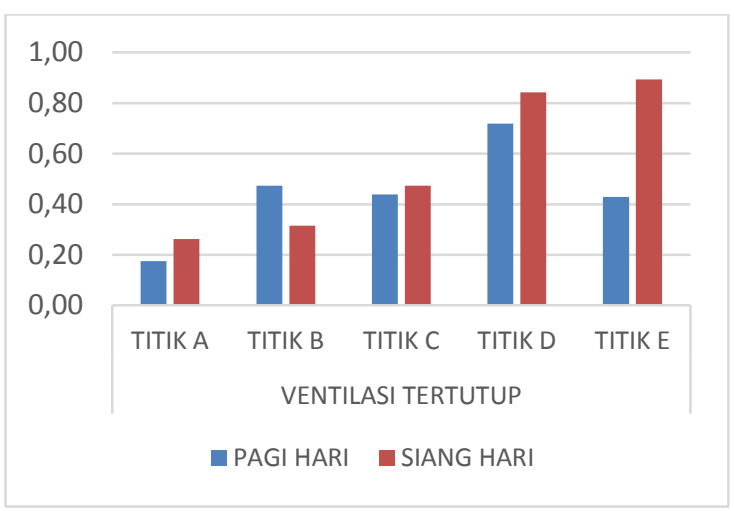

Gambar 12. Diagram Hasil Pengukuran

Volumetric Air Flow Rate Saat Ventilasi Tertutup (m3/menit/orang)

Berdasarkan hasil pengukuran saat ventilasi tertutup, volumetric air flow rate yang menunjukkan jumlah arus volume udara bersih yang masuk ke ruangan dengan kapasitas 76 orang cenderung fluktuatif pada pagi hari dan cenderung naik dari titik A ke titik E pada siang hari.

Pada pagi hari, jumlah arus volume udara bersih yang masuk pada titik A sebesar 0,18 $\mathrm{m} 3 /$ menit/orang lalu naik pada titik B kemudian turun pada titik $\mathrm{C}$ dan naik kembali hingga mencapai arus volume udara bersih tertinggi pada titik D sebesar $0,72 \mathrm{~m} 3 / \mathrm{menit} /$ orang. Pada siang hari volume udara bersih yang masuk cenderung semakin tinggi dari titik A hingga ke titik E. Jumlah volume udara bersih terendah yaitu $0,26 \mathrm{~m} 3 / \mathrm{menit} /$ orang pada titik A semakin bertambah jumlahnya hingga ke titik $\mathrm{E}$ yang tertinggi sebesar $0,89 \mathrm{~m} 3 / \mathrm{menit} /$ orang.

Dengan kapasitas ruang 76 orang, pada saat ventilasi tertutup, volume udara bersih yang masuk pada ruang tunggu poliklinik RSND tersebut masih kurang dari yang dianjurkan menurut (Syamsiyah Nur. R, 1995) dalam (Anam et al., 2014) yaitu dibawah 0,9 $\mathrm{m}^{3} /$ menit/orang. Hal ini disebabkan kurangnya cross ventilation dan kurangnya aliran udara yang keluar/masuk ruangan.

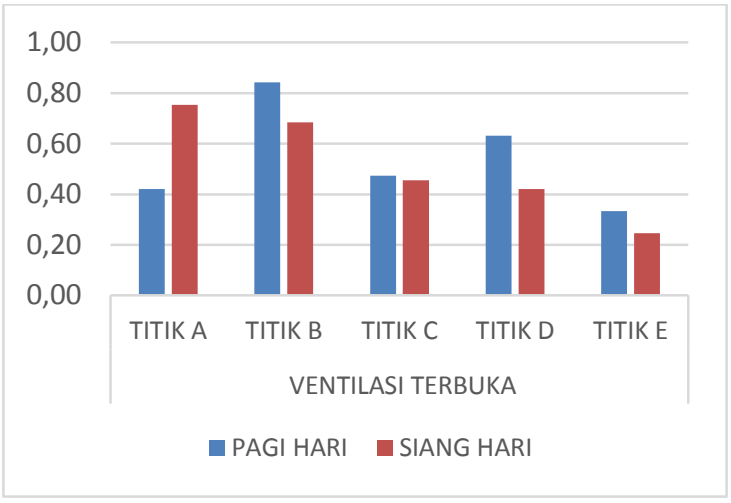

Gambar 13. Diagram Hasil Pengukuran Volumetric Air Flow Rate Saat Ventilasi Terbuka (m3/menit/orang)

Pada saat ventilasi terbuka, volumetric air flow rate yang menunjukkan jumlah arus volume udara bersih yang masuk ke ruangan dengan kapasitas 76 orang cenderung fluktuatif pada pagi hari dan cenderung menurun dari titik $\mathrm{A}$ ke titik E pada siang hari.

Pada pagi hari, jumlah arus volume udara bersih yang masuk pada titik A sebesar 0,42 m3/menit/orang lalu naik pada titik B yang merupakan arus tertinggi sebesar 0,84 m3/menit/orang kemudian turun pada titik $\mathrm{C}$ dan naik kembali pada titik D lalu turun hingga mencapai arus terendah pada titik $\mathrm{E}$ sebesar $0,33 \mathrm{~m} 3 / \mathrm{menit} /$ orang. Pada siang hari volume udara bersih yang masuk cenderung semakin menurun dari titik A hingga ke titik E. Jumlah volume udara bersih tertinggi yaitu 0,75 m3/menit/orang pada titik A semakin menurun jumlahnya hingga ke titik $\mathrm{E}$ yang terendah sebesar $0,25 \mathrm{~m} 3 / \mathrm{menit} /$ orang.

Pada saat ventilasi terbuka, titik A, B dan C volume udara yang masuk lebih tinggi bila dibandingkan pada saat ventilasi tertutup. Namun pada titik D dan E cenderung lebih sedikit. Walaupun ventilasi telah dibuka semua, secara keseluruhan volume udara bersih yang masuk juga masih kurang dari yang dianjurkan menurut (Syamsiyah Nur. R, 1995) dalam (Anam et al., 2014) yaitu dibawah 0,9 $\mathrm{m}^{3} /$ menit/orang. Hal ini dapat disebabkan karena kurang optimalnya jenis/ tipe bukaan yang digunakan dan kurangnya cross ventilation. 


\section{Penghitungan Nilai Pergantian Udara}

Dapat dilihat pada hasil perhitungan nilai $\mathrm{N}$ (kali/jam); yaitu nilai pergantian udara untuk tiap jam dengan rumus [1], maka hasilnya :

Table 3. Hasil Penghitungan Nilai Pergantian Udara (kali/jam)

\begin{tabular}{|c|c|r|r|r|r}
\hline $\begin{array}{c}\text { PAGI } \\
\text { HARI }\end{array}$ & $\begin{array}{c}\text { TITIK } \\
\text { A }\end{array}$ & $\begin{array}{c}\text { TITIK } \\
\text { B }\end{array}$ & $\begin{array}{c}\text { TITIK } \\
\text { C }\end{array}$ & $\begin{array}{c}\text { TITIK } \\
\text { D }\end{array}$ & $\begin{array}{c}\text { TITIK } \\
\text { E }\end{array}$ \\
\hline $\begin{array}{l}\text { Ventilasi } \\
\text { Tertutup }\end{array}$ & 2,2 & 6,0 & 5,6 & 9,1 & 5,5 \\
\hline $\begin{array}{l}\text { Ventilasi } \\
\text { Terbuka }\end{array}$ & 5,3 & 10,7 & 6,0 & 8,0 & 4,2 \\
\hline
\end{tabular}

\begin{tabular}{|c|r|r|r|r|r}
\hline $\begin{array}{c}\text { SIANG } \\
\text { HARI }\end{array}$ & $\begin{array}{c}\text { TITIK } \\
\text { A }\end{array}$ & $\begin{array}{c}\text { TITIK } \\
\text { B }\end{array}$ & $\begin{array}{c}\text { TITIK } \\
\text { C }\end{array}$ & $\begin{array}{c}\text { TITIK } \\
\text { D }\end{array}$ & $\begin{array}{c}\text { TITIK } \\
\text { E }\end{array}$ \\
\hline $\begin{array}{l}\text { Ventilasi } \\
\text { Tertutup }\end{array}$ & 3,3 & 4,0 & 6,0 & 10,7 & 11,3 \\
\hline $\begin{array}{l}\text { Ventilasi } \\
\text { Terbuka }\end{array}$ & 9,6 & 8,7 & 5,8 & 5,3 & 3,1 \\
\hline
\end{tabular}

Berdasarkan tabel hasil perhitungan nilai pergantian udara diatas, untuk lebih jelasnya dapat dilihat pada diagram berikut ini :

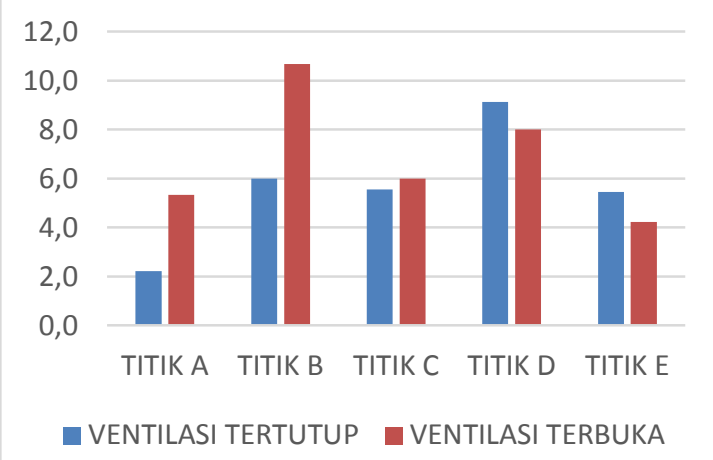

Gambar 14. Diagram Hasil Penghitungan Nilai Pergantian Udara (kali/jam) Pada Pagi Hari

Pada pagi hari, nilai pergantian udara pada ruang tunggu poliklinik RSND cenderung fluktuatif. Pada saat ventilasi tertutup, nilai pergantian udara pada titik A sebesar 2,2 kali/ jam, kemudian naik pada titik B sebesar 6 kali/jam, lalu turun pada titik C sebesar 5,6 kali/ jam, lalu naik kembali hingga mencapai nilai puncak sebesar $9 \mathrm{kali} / \mathrm{jam}$ pada titik D dan turun kembali pada titik E sebesar 5,5 kali/jam. Berdasarkan (Kementrian Kesehatan Republik Indonesia, 2012) tentang Pedoman Teknis Prasarana Sistem Tata Udara Pada Bangunan Rumah Sakit, pada titik B dan D nilai pergantian udara sudah sesuai dengan standar minimum yang direkomendasikan yaitu 6 kali/jam sedangkan pada titik A, C dan E masih belum memenuhi.

Pada saat ventilasi terbuka, nilai pergantian udara pada titik A sebesar 5,3 kali/ jam, kemudian naik dan mencapai nilai tertinggi pada titik B sebesar 10,7 kali/jam, lalu turun pada titik $\mathrm{C}$ sebesar $6 \mathrm{kali} / \mathrm{jam}$, lalu naik kembali sebesar $8 \mathrm{kali} / \mathrm{jam}$ pada titik D dan turun kembali pada titik E sebesar 4,2 kali/jam. Berdasarkan (Kementrian Kesehatan Republik Indonesia, 2012) tentang Pedoman Teknis Prasarana Sistem Tata Udara Pada Bangunan Rumah Sakit, pada titik B, C dan D nilai pergantian udara sudah sesuai dengan standar minimum yang direkomendasikan yaitu 6 kali/jam sedangkan pada titik A, dan E masih belum memenuhi.

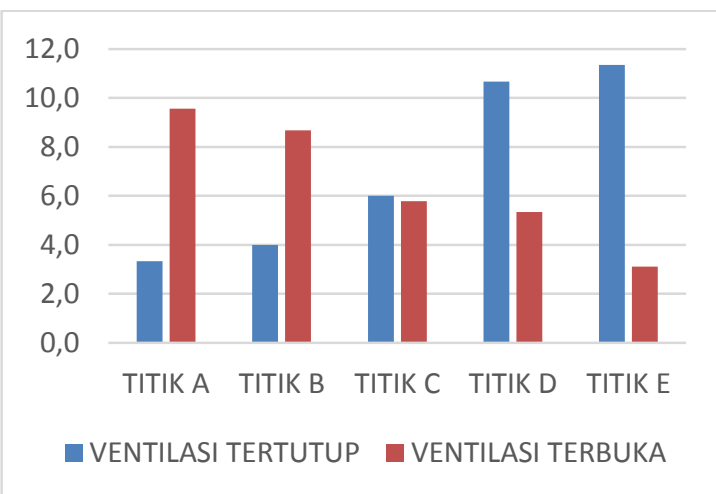

Gambar 15. Diagram Hasil Penghitungan Nilai

Pergantian Udara (kali/jam) Pada Siang Hari

Pada siang hari, nilai pergantian udara pada ruang tunggu poliklinik RSND naik dari titik A ke titik E pada saat ventilasi tetutup, namun sebaliknya pada saat ventilasi terbuka yaitu cenderung menurun dari titik A hingga ke titik E. Pada saat ventilasi tertutup, nilai pergantian udara pada titik A merupakan nilai teendah sebesar 3,3 kali/ jam kemudian terus mengalami kenaikan hingga titik E dengan nilai tertinggi sebesar 11,3 kali/jam. Berdasarkan (Kementrian Kesehatan Republik Indonesia, 2012) tentang Pedoman Teknis Prasarana Sistem Tata Udara Pada Bangunan Rumah Sakit, pada titik C, D dan E nilai pergantian udara sudah sesuai dengan standar minimum yang direkomendasikan yaitu 6 kali/jam sedangkan pada titik A dan B masih belum memenuhi. 
Pada saat ventilasi terbuka, nilai pergantian udara pada titik A sebesar 9,6 kali/jam yang merupakan nilai tertinggi kemudian terus mengalami penurunan hingga titik $\mathrm{E}$ terendah sebesar 3,1 kali/jam. Berdasarkan (Kementrian Kesehatan Republik Indonesia, 2012) tentang Pedoman Teknis Prasarana Sistem Tata Udara Pada Bangunan Rumah Sakit, pada titik A dan B nilai pergantian udara sudah sesuai dengan standar minimum yang direkomendasikan yaitu 6 kali/jam sedangkan pada titik C, D dan E masih belum memenuhi.

Secara keseluruhan, nilai pergantian udara di ruang tunggu poliklinik RSND pada saat ventilasi terbuka ini cenderung lebih tinggi bila dibandingkan pada saat kondisi ventilasi tertutup. Nilai pergantian udara dipengaruhi jumlah udara yang masuk (volumetric flow rate) dan juga adanya pengaruh dari udara dari luar ruangan. Kurangnya cross ventilation dapat mengakibatkan kurangnya pergantian udara dari dalam ruang ke luar ruang maupun sebaliknya, sehingga memungkinkan terjadinya pengumpulan udara kotor dari lingkungan luar yang terbawa masuk ke dalam ruang.

\section{KESIMPULAN}

Berdasarkan hasil penelitian yang telah dilakukan, suhu, kelembaban dan volume udara bersih yang masuk masih belum memenuhi standar yang direkomendasikan. Sedangkan untuk nilai pergantian udara perjam sudah sesuai dengan standar minimum yang direkomendasikan pada beberapa titik, namun pada titik yang lain masih belum memenuhi. Hal ini berkaitan dengan ventilasi/bukaan yang ada di ruang tunggu poliklinik RSND lantai 2 ini.

Penghawaan alami melalui ventilasi memungkinkan adanya aliran udara yang masuk ke dalam ruang. Dengan adanya aliran udara yang masuk dapat sedikit menurunkan suhu dan kelembaban dalam ruang. Suhu dan kelembaban pada ruang dapat berpengaruh pada kesehatan dan kualitas udara dalam ruang terhadap perkembangbiakan mikroorganisme.

Tipe/jenis bukaan dan optimalisasi cross ventilation juga memiliki pengaruh terhadap kualitas udara dalam ruang. Kurang optimalnya jenis/ tipe bukaan yang digunakan dan kurangnya cross ventilation dapat mengurangi volume udara bersih yang masuk ke dalam ruang. Selain itu, kurangnya cross ventilation juga dapat mengakibatkan kurangnya pergantian udara dari dalam ruang ke luar ruang maupun sebaliknya, sehingga memungkinkan terjadinya pengumpulan udara kotor dari lingkungan luar yang terbawa masuk ke dalam ruang.

Oleh karena itu, dapat ditarik kesimpulan bahwa ventilasi alami memiliki pengaruh yang signifikan terhadap kualitas udara yang berkaitan dengan fenomena sick building syndrome.

Untuk mendapatkan kualitas udara yang baik dan mengurangi resiko sick building syndrome, diusahakan agar di dalam ruangan selalu ada pergerakan atau sirkulasi udara (cross ventilation). Pengaturan ruangan perlu mempertimbangkan letak ventilasi baik dan juga pemilihan jenis ventilasi yang sesuai sehingga dapat mengurangi beban energi dengan memanfaatkan ventilasi alami yang lebih maksimal. Dengan demikian pertukaran udara dalam ruang menjadi lebih efektif, udara bersih dapat masuk ke dalam ruang dan udara kotor tidak menumpuk di dalam ruangan.

\section{UCAPAN TERIMAKASIH}

Tim Peneliti mengucapkan terimakasih kepada pihak Rumah Sakit Nasional Diponegoro yang telah memberikan izin kepada kami untuk melaksanakan penelitian ini.

\section{REFERENSI}

Anam, K., Islam, R. Z., Studi, P., Arsitektur, T., Teknik, F., Surakarta, U. M., ... Penelitian, M. (2014). Tingkat pencapaian penghawaan alami pada omah sinten heritage hotel dan resto di surakarta. Sinektika, 14(1), 172-179.

Camelia, A. (2011). Sick Building Syndrome and Indoor Air Quality. Jurnal Ilmu Kesehatan Masyarakat, 2(2), 79-84.

Jayanti, L., Manyullei, S., \& Bujawati, E. (2016). Kesehatan Lingkungan Udara Ruang Rawat Inap Rumah Sakit Syekh Yusuf Kabupaten Gowa. Higiene, 2(1), 33-40.

Juliana Bekti Susilaning Budi, Khairunnisa Fifthariski, Sri Yuliani, W. S. (2018). 
Strategi Implementasi Desain Hijau Untuk Optimalisasi Penghawaan Alami Pada Bangunan Tinggi. 3680(i), 155164.

Kelly, P. O., Maupetit, F., \& Robine, E. (2002). Indoor Air quality In Schools : The Impact Of Ventilation Conditions And Indoor Activities. Proceeding : Indoor Air 2002, 109-114.

Kementrian Kesehatan Republik Indonesia. (2012). Pedoman Teknis Prasarana Sistem Tata Udara pada Bangunan Rumah Sakit.

Menteri Kesehatan Republik Indonesia. (1998). Keputusan Menteri Kesehatan Nomor 261/MENKES/SK/II/1998 Tentang: Persyaratan Kesehatan Lingkungan Kerja.

Menteri Kesehatan Republik Indonesia. (2004). Keputusan Menteri Kesehatan Republik Indonesia Nomor 1204/MENKES/SK/X/2004 Tentang Persyaratan Kesehatan Lingkungan Rumah Sakit.

Moerdjoko. (2004). Kaitan Sistem Ventilasi Bangunan Dengan Keberadaan Mikroorganisme Udara. Dimensi Teknik Arsitek, 32(1), 89-93.

Pemerintah Provinsi DKI Jakarta. (2012). Vol. 2 Sistem Pengkondisian Udara \& Ventilasi.

Rachmatantri, I., Hadiwidodo, M., \& Huboyo, H. S. (2015). Pengaruh Pengguna Ventilasi (AC dan Non-AC) terhadap Keberadaan Mikroorganisme Udara di Ruang Perpustakaan (Studi Kasus:Perpustakaan Teknik Lingkungan dan Perpustakaan Biologi Fakultas MIPA Universitas Diponegoro Semarang). Jurnal Teknik Lingkungan, 4(1), 1-2.

Syamsiyah Nur. R. (1995). Materi Kuliah Fisika Bangunan I. Surakarta: Universitas Muhammadiyah Surakarta.

Talarosha, B. (2018). Konsentrasi CO2 pada Ruang Kelas dengan Sistem Ventilasi Alami sebuah Penelitian Awal. Jurnal Lingkungan Binaan Indonesia, 6(1), 2227. https://doi.org/10.32315/jlbi.6.1.22

U.S. Department Of Health And Human Services. (2011). Musculoskeletal Disorders and Workplace Factors. In National Institute for Occupational Safety and https://doi.org/10.1007/s10670-0139512-x

Vidyautami, D., Huboyo, H. ., \& Hadiwidodo, M. (2015). Pengaruh Penggunaan Ventilasi (AC Dan Non AC) Dalam Ruangan Terhadap Keberadaan Mikroorganisme Udara (Studi Kasus: Ruang Kuliah Jurusan Teknik Sipil Universitas Diponegoro). Jurnal Teknik Lingkungan, 4(1), 1-8. 